\title{
Strategies for Competitive Advantage in Value Added Tea Marketing
}

\author{
H.M.U.N. Herath and S. De Silva ${ }^{1 *}$ \\ Postgraduate Institute of Agriculture \\ University of Peradeniya \\ Sri Lanka
}

\begin{abstract}
At present the world tea market is rapidly growing with emerging customer needs. The importance of a change from bulk tea exports to value added tea products is highlighted in literature to face the challenges in an increasingly competitive beverage market. Firms failing to address the competitive forces by developing their marketing strategies will lose out to competitors. Thus, marketing strategies adopted by the company leaders, directing their firms towards gaining competitive advantage in the value added tea industry are discussed in this paper. Data were gathered through interviews with the founders of nine firms using an interview guide and using records at the Sri Lanka Tea Board and the Sri Lanka Customs. The results revealed that brand building, niche marketing, product differentiation, cost leadership, and customer focus were the most prominent strategies adopted by the firms. Opening up new markets abroad, fair trade, environmental sustainability, and faster delivery were identified as important strategies that differentiated firms from competitors and placed them among the market leaders. It was also revealed that the strategic decisions could be attributed to vision of the leaders, risk taking, their enthusiasm and commitment. Identifying marketing strategies depending on the firm's capabilities and innovations, is therefore, found vital for the value added tea export firms to achieve business success as well as to make substantial contribution to the Sri Lankan economy.
\end{abstract}

Key words: competitive advantage, innovation, leadership, strategies, value added tea

\section{INTRODUCTION}

The story of Ceylon tea can be traced back over 200 years ago, when the country was a British colony. Ceylon tea as a beverage has been enjoyed by people all over the world for generations. It still has the value and interest as a beverage with many health benefits. Over a significant period of time, Sri Lankan tea industry has made progress in expanding the value added tea products. At present, Sri Lanka's value added tea exports include instant tea, tea bags, iced tea, flavoured tea, green tea, and organic tea. Hot and cold water soluble instant tea, have become an important ingredient in the making of tea mixes. The range of natural drinks is widening all the time, and are available in unsweetened, zero calorie/carbohydrate, Ready to Drink (RTD) bottled, green or black teas, mixed with kiwi and pear, berry and plum, cherry, orange and spice, ginger and peach, blackberry and sage, raspberry and quince, mango and mint (Modder and Amarakoon, 2002). While catering to the needs of the conventional Ceylon tea lovers, Sri Lanka has to face the challenges in an increasingly competitive beverage market as the variety of teas in the world is now increasing while consumption of unbranded tea is declining (Wanninayake and Disanayake, 2006).

\footnotetext{
To whom correspondence should be addressed: saliyades@pdn.ac.lk

Department of Agricultural Extension, Faculty of Agriculture University of Peradeniya, Peradeniya, Sri Lanka
} 
However, according to the statistics of the Sri Lanka Tea Board (2010) more than 50\% of the tea exports are still in the form of traditional bulk tea. Present Sri Lankan value added tea exports are around 40 to $45 \%$ of total tea exports. According to Table 1, it is apparent that all kinds of value added tea products fetch a higher price than bulk tea exports.

Table 1. Ceylon tea exports and prices in February 2010

\begin{tabular}{lccc}
\hline Category & Quantity (kg) & Percentage & Avg. Price (Rs./kg) \\
\hline Tea in bulk & $25,699,961$ & 58.00 & 443.91 \\
Tea in packets & $12,515,485$ & 28.01 & 459.36 \\
Tea in bags & $2,789,410$ & 6.24 & 851.49 \\
Instant tea & 229,768 & 0.51 & 797.19 \\
Green tea & 669,285 & 1.49 & 863.79 \\
Other & $2,771,661$ & 6.20 & 695.04 \\
\hline
\end{tabular}

Source: Sri Lanka Tea Board (2010)

Exporters have now realized the difference between trading a commodity (black tea in bulk) and marketing a consumer product (value added tea in branded pack). Commodities are products that consumers cannot differentiate from one another as they all seem to serve the same need and deliver the same value. Consumer brands in contrast are differentiated with compelling characteristics that make it better than other offerings in the product category. Ceylon tea will remain vulnerable to downward demand-led price pressure as long as it is treated as commodity.

Sri Lanka is conscious of the need to bring about vertical integration in its traditional tea exports and is now into converting a major portion of tea exports to consumer packs and other forms of value added exports, meeting the requirements of more sophisticated markets. Creating a stable position in the market place and coping successfully with the competitive forces should define Sri Lanka's competitive strategy in the global tea industry. Competitive strategy concentrates on the industry, while competitive advantage concentrates on the firm. A competitive advantage exists when the firm is able to deliver the same benefits as competitors but at a lower cost (cost advantage) or deliver different benefit of those competing products (differentiation advantage). Thus a competitive advantage enables the firm to create superior value for its customers and superior profits for itself (Porter, 1985).

Porter (1980) has identified cost advantage and differentiation as the two strengths of a firm which can be applied in either broad or narrow scopes resulting in three generic strategies i.e. cost leadership, differentiation and focus strategies. A combination of generic strategies at the broadest level could help firm outperform its competitors in the long run. Among the strategies are differentiating product, developing consumer loyalty through market niches and adopting a low cost focus (Choudhry et al., 1997). Maintaining customer focus, superior product quality, extensive distribution contracts, accumulated brand equity and positive company reputation are competencies through which a firm can gain competitive advantage. Competitive advantage may also arise from low cost production techniques, patents and copyrights, government protected monopoly positions and superior employee and management traits (De Silva, 2006). 
Those firms and industries failing to address the competitive forces by developing their strategies will lose out to competitors. They will lose high margin business to firms who have focused efficiently on high margin target markets with highly differentiated products. Product innovation strategies are defined as "the ways by which a firm's resources and advantages are managed to develop products in order to overcome competition or to exploit opportunities" by Luck and Prell (2005). New thinking, new orientation and intelligent moves are required for the success of strategic move because the competitors are equally powerful. The history of successful business organizations reveals how they have designed and implemented change to support business strategies that have resulted in business expansions, acquisitions and organizational restructuring etc. through the enduring efforts of the organizational leadership.

Organizations that work with new knowledge and create technological applications will become the most important segment of successful economies around the world. It has been observed that it is difficult to sustain these advantages in the long run in a fast changing competitive world, without conscious effort from the part of the firm. Competitive advantage can be sustained only through building an organization that is alert and active enough to be able to find a new competitive advantage through innovations when the old competitive advantage wears out (De Silva, 2006).

In fact, not all firms in marketing would opt for innovate products, at their own risk, because many new products, especially radically new products fail to generate interest among buyers. In view of the risks and costs involved in innovations, the leaders or the company CEOs who have the courage to innovate and to invest on Research and Development (R\&D) are expected to be individuals with special capabilities, and drive for achievement. A leader must be able to articulate an inspiring vision; one that others are willing to pursue even if it requires sacrifices. Also, they should articulate a persuasive strategy, one that makes pursuit of the vision under his or her leadership appear to be potentially successful (Ackoff, 2005).

Entrepreneurial leaders are believed to have a tendency to exploit opportunities outside their domestic markets leading to competitive advantage. Thus, investigating market and innovation strategies adopted by firms towards gaining competitive advantage in relation to value added tea exports in Sri Lanka would be vital to develop the tea sector.

The specific objective of this paper, therefore, is to analyze the marketing and product innovation strategies adopted by the leaders / Chief Executive Officers (CEOs), who were in all occasions the founders of the firms investigated in this study. The study attempts to discuss the strategies adopted by the firms with the objective of finding its contribution to the positions held by the firm in the value added tea industry. Sharing the experiences of the successful CEOs with future managers and decision makers with the aim of developing their abilities in formulating strategies is another objective. The study was conducted as a qualitative investigation of selected value added tea marketing firms in Sri Lanka.

\section{METHODOLOGY}

Case study design was adopted and nine cases were included in the study. Selection of the companies for the study was done using the records of tea exporters issued by the National Chamber of Exporters, National Chamber of Commerce and the Tea Board. The criteria for selection included pioneering companies in product innovation, firms with a wide range of value added tea products, and those firms that continued new product development. As 
defined in the OSLO manual (2005) innovation includes both products and processes; product innovation is the implementation of a new or significantly improved product /service whereas process innovation is implementing a new marketing method, or a new organizational method in business practices. Nine companies selected for the study included three pioneering companies in product innovation and six others with a variety of value added products including flavoured tea, green tea, tea bags, gift packs and herbal tea. They comprised of Amazon Trading, MJF Group, Millennium Teas, Tea Masters Ceylon, Ni-Cey International, Bio Foods, Imperial Teas, HVA Foods and Ranfer Teas. English letters (A to I) were randomly allocated to identify them in the results and discussion section to maintain their anonymity. Details of innovative products of the firms were accessed by visiting the company websites and by contacting relevant managers in those firms ${ }^{2}$. Several companies were discarded after initial selection due to the inability of contacting the CEO as the key respondent of the case.

Gathering data was done through interviews conducted with the Chief Executive Officers of the firms. A detailed interview guide was developed covering personal data such as education, family background, their childhood, start of the business and firm data including product innovation strategies used to penetrate export markets and vision of the CEOs. Recorded interviews were transcribed and information related to the strategies adopted by the firms and product innovations as well as market innovation practices were extracted. Qualitative data gathered through interviews were supported with statistics of value added tea export quantities and value of exports obtained from the Sri Lanka Tea Board and the Sri Lanka Customs. The company websites and published and unpublished reports of relevant organizations were indispensable sources of information. Descriptive analysis was adopted in describing the relationships among the market or innovative strategies and their effects on the value of sales or the sales volumes. In addition, the role of the leader was studied in relation to the development of strategies.

\section{RESULTS AND DISCUSSION}

Different market and product innovation strategies adopted by the CEOs of the firms will be discussed in this section. Analysis will be presented as individual cases and the strategies followed by each firm will be discussed under different topics.

\section{Producer owned ethical tea brand}

The world famous brand of tea produced by Company I brought back the real taste of Ceylon tea to the consumers worldwide. It is the world's first producer owned tea brand (Fonseka, 2009). The founder and chairman of the company strategically planned to eliminate the exploitation of the Ceylon tea industry by the multinationals. His vision was to re-establish Ceylon tea as the finest tea on earth. According to the chairman who has been in the field for over sixty years, it was his childhood dream to launch his own brand of tea and he continued to strategize the action plan to launch his brand of "Pure Ceylon Tea". The inspiring role of the founder of this company in building an international brand introduced value addition to the tea industry. He pioneered the concept of single origin tea, which gives a unique identity to the location and origin of tea. 'Company I' is the largest exporter of tea bags and its brand of tea is among the top ten brands in the world. In Australia it is the number two brand in

Firms were not prepared to reveal detailed information about the level of new product development prior to the interviews. 
mainstream black tea and it is the number one brand in New Zealand. Tea is marketed by the company in 93 countries and its consumer base is increasing steadily. It is the country's largest exporter of tea bags (Table 2).

Table 2. Weight and values of exported black tea bags in 2009

\begin{tabular}{lrr}
\hline Company & Weight $(\mathbf{k g})$ & Value (Rs. Millions) \\
\hline A & 20,560 & 15.512484 \\
B & 209,684 & 161.353700 \\
C & 65,571 & 56.986413 \\
D & 64 & 0.242052 \\
E & 69,044 & 45.756531 \\
F & 184,303 & 179.510146 \\
G & 17,975 & 60.374641 \\
H & 64,952 & 33.214819 \\
I & $2,709,335$ & 2726.055592 \\
\hline
\end{tabular}

Source: Sri Lanka Customs (2010)

This world famous brand of tea was launched first in Australia in 1988 and then in New Zealand in the following year. One significant marketing strategy followed by the brand is maintaining freshness and quality. As a strategic measure to ensure freshness, bulk tea is directly brought from their tea gardens for the ongoing consignment. Storage of tea for months in the factory is not recommended as a strategy to ensure freshness. Tea is shipped within days to the tea drinkers around the world to ensure freshness and quality.

Operating as a family business, Company I had vertically integrated growing, manufacturing, packaging, and exporting functions. These have been accomplished with a single focus especially under the management of the founder and chairman whose long term experience in the industry, dedication and commitment contributed towards making Ceylon tea world famous. This is the company that introduced for the first time packaging at origin-source, branding and marketing cutting out middlemen's profits.

One of the most valued strategies adopted by the chairman is caring for the consumers, sharing with the workers and the company reinvests the earnings in tea industry for making tea sustainable. The chairman believes that consumers determine the success and failure of a new brand and success of their brand of tea is dependent largely on consumer trust, confidence on its freshness and quality. This brand of tea is the role model of marketing success of a producer country taking its crop to the market and retaining in Sri Lanka all the profits from value addition branding and marketing, which was taken away by multinationals leaving the industry and Sri Lanka in poverty.

\section{Tea at low cost}

The innovative concept of the instant tea vending machine was introduced to Sri Lanka by Company A. Instant tea was not popular in Sri Lanka and the market was dominated by instant coffee (Nescafe) when the chairman of the company identified the potential for instant tea in the local market. He further studied about instant tea and procured a tea 
vending machine from Chennai, India after paying for the technology, which was modified subsequently to match the local conditions. Instant tea was introduced to the local market in year 2002, using the imported technology and local ingredients. Instant tea powder was provided by the James Finlay company, which owned the only instant tea plant in the country and totally dissolving milk powder was provided by the Milco (Pvt.) Ltd.. While operating in the local market promoting instant tea with the tea vending machine, other value added products such as flavoured tea and organic tea in packs are exported by this firm.

The two main sources of competitive advantage for 'Company A' are low cost and product differentiation. They have limited their advertising expenditure and mainly focus on gaining publicity at local and international exhibitions. They promote instant tea at local exhibitions and social events catering to the local consumers who still prefer a cup of tea to carbonated beverages. They serve instant tea both as hot and iced beverages available in several flavours. There are occasions when the company serves instant tea as the official tea caterer. This was a strategy adopted by the company for promoting their tea vending machine with a low advertising expenditure. They also used this strategy to introduce the home tea maker to help with the busy Sri Lankan housewives who are culturally accustomed to welcome visitors with a cup of tea.

Tea blending has been outsourced by this firm as a strategic measure to overcome unnecessary burden in maintaining machinery. Another reason behind hiring machines is to avoid the financial risk involved in the investment due to the high cost of machines. Nevertheless, strategic key result areas such as packaging of value added tea are handled by the company in their own factory.

\section{Branding and niche marketing}

Branding and niche marketing are identified as the two main strategies adopted by 'Company B'. This company is an outstanding exporter of value added tea headed by a person with over 30 years of experience in the tea industry. The annual exports of the firm exceed 12 million $\mathrm{kg}$ valued over 52 million US dollars. During the year 2007, the value added exports amounted to $60 \%$ of the company's export volume. Branded exports of the company account for approximately $90 \%$ of total exports. As mentioned by the CEO during the interviews, the branding strategy is important for securing the loyal customers. The general practice is that the customers move to competitive companies looking for better prices. Therefore, branding is the best strategy to retain the customers. Branding and value addition go hand in hand. According to the CEO value addition started with their entry into the Russian market. The significant strategic move of the company was entering the Russian market immediately after its transformation from the former Soviet Union at a time when the market was absolutely free from competitors. Although it was a risky decision it demonstrated the ability of the leader to visualize the future market opportunities.

The entire operation of the manufacturing process including buying tea, processing, blending and packing is handled by the company. They own two factories, tea bagging machines, processing plants (to add flavours) and packaging units within the premises. The designing department comes up with creative package designs. Their brand of tea is marketed in more than 60 countries today and they focus their sales in the niche markets such as Russia. Maintaining close contacts with customers and their families and visiting and spending time with them have helped to understand customer preferences and study their tea drinking habits. This approach has enabled the company to develop best teas to match customer requirements. Frequent foreign visits are made by company representatives for business transactions as well as for exploring markets overseas. 


\section{Niche marketing and innovation through Research and Development}

Company $\mathrm{C}$ who pioneered in exporting RTD iced tea is committed to provide natural beverages to discerning global consumers. The main focus of the company is providing value added tea products especially their innovative RTD iced tea to the niche markets. The US market is very strong for RTD and conveniently packed tea. Presently this company is registered in over 42 countries. Their brand entered the Chinese market with a strategic partnership and the group has now opened 10 exclusive tea outlets in China.

Having identified the growing demand for carbonated drinks among the young generation in the western world, the chairman strategically introduced iced tea to those markets gaining competitive advantage by being the first Sri Lankan company exporting its own brand of RTD tea. He used this strategy to sustain the market for tea as the demand for tea among children has been notably declining. This is the segment to be approached for the reason that they will be the potential consumers in the future markets. Unless the habit of drinking tea is established among the young generation, income earning through exporting tea to Europe and Western world would be doubtful in the future. He strategically made use of the shifting demand towards carbonated beverages and developed their preferred type of beverage with tea. As mentioned in their mission statement, they attempt to cater to the needs of the customers by offering environmentally friendly products through constant innovative experiments in their laboratories. The chairman claims that this is the first Sri Lankan tea company to own a laboratory where the R\&D team conduct experiments on tea-based products. Establishment of the industry's first standardized laboratory by the company shows its strong commitment towards research and development.

\section{Cost leadership in tea marketing}

Company D is adopting a different strategy compared with the other firms in the study. More than an exporter of value added tea, the CEO recognizes his company as a marketing organization. The firm is managed by a team in Sri Lanka, while the chairman is coordinating the business from Canada. They are very strongly established in the North American market. Their business is considered to be in the category of beverage industry rather than tea. Therefore, they concentrate on the marketing aspects of value added tea and have moved out of manufacturing. The company has taken a strategic decision not to run factories, as the company perceives it is not viable in Sri Lanka. Hence manufacturing has been outsourced to Akbar Brothers. The view of the CEO is that there is no value addition in manufacturing. Value addition is a marketing aspect and the important thing is managing the whole operation including packaging and designing.

As a strategy to increase the effectiveness of the whole operation the CEO has reduced his work force by two hundred people and is free from the burden of managing a large workforce. This strategic move enabled the company to run the business devoid of managing a huge work force and saves time to effectively focus on building a brand, which is the long term vision of the founder. The main strategy of company $\mathrm{D}$ is therefore building a brand which is marketable. Thus, the firm has totally moved out of manufacturing and operating as a marketing organization. They have strategically eliminated the intermediaries and the whole market operation is managed by distributors identified by the company. "They are not brand loyal. They just work for the market and possibly can be taken by another person" said the CEO describing the jeopardy in occupying the intermediaries, who keep $60 \%$ of the margin. 
The innovative capacity of the company lies in the hands of the strong and creative R\&D team involved in designing, packaging, product development and customer research. One important strategy in developing innovative products and winning the competitive market is producing for the customer requirement. "We strictly produce what the customer wants" explained the CEO. This company is very much 'brand conscious' and their bulk tea sale is at zero level. Value addition in his opinion is a marketing strategy and the company never attempts to generate revenue through exporting 'Pure Ceylon Tea'.

\section{Responding to customer needs and strategic partnership}

According to the CEO of Company E, who has over 40 years of experience in tea exports, one of the important strategies adopted by them is to study the market and observing the economies of the countries who buy their teas. It is essential to have a basic idea about the particular type of tea required for those markets and lot of research is therefore needed in those areas. It is important to study how tea is marketed, distributed and consumed.

Another key factor identified by the CEO as strategically important in exports is to employ a trustworthy partner at the other end. Choosing the wrong person as experienced by him, will ruin all business efforts. They had the opportunity to serve as the exclusive agents of famous international brands (e.g. famous Five Roses brand in South Africa). Total tea requirement for the Five Roses brand is supplied by this company. After many years of operation, it was decided to market their own brand and value added products mainly in external markets. With time their own brands were developed and strategically moved into countries such as Fiji. Research and development is one of the main aspects of the organization. Always they look forward to explore into new fields and think what is the next stage? For example now the tea bags are popular in the market, what will be the next, and this helps to keep the organization developing products to meet customer needs.

\section{Fair trade of organic tea}

The vision of Company G, headed by a veteran scientist, is to follow agricultural practices in an environmentally friendly manner, and then to support the country's economy by marketing value added products. The firm was started as a tea company with this vision and their mission is directed to see the socio economic development and wellbeing of small farmers. The main strategy employed by this organization therefore is to engage in revenue generation with value added products including tea and spices while giving special emphasis in protecting the environment. With this intention the CEO introduced the 'Fair Trade' concept for the benefit of small and medium farming community.

The chairman identified that the best option to capture the European market was to export organic tea. This company is the largest Sri Lankan exporter of organic tea and right from the beginning concentrated on value added tea because lot of energy needs to be put forth to penetrate the market with conventional tea. Green tea or organic tea became a very good innovative type of approach to penetrate the international market. This is the first Sri Lankan tea company manufacturing green tea without importing the machinery. They were successful in manufacturing green tea called "Ceylon Cha" with the machinery designed by the company for which they received patent right. Having identified the problem with the Sri Lankan green tea - the bitter taste, the CEO who is a food scientist managed to produce green tea without any bitter character in the cup. He strategically made the market entry through organic tea at a time when organic tea was not well known. There were some companies working on organic teas and the strategy adopted by the CEO was exporting it 
directly to Germany. This company at present is Sri Lanka's largest exporter of organic green tea (Fig. 1).

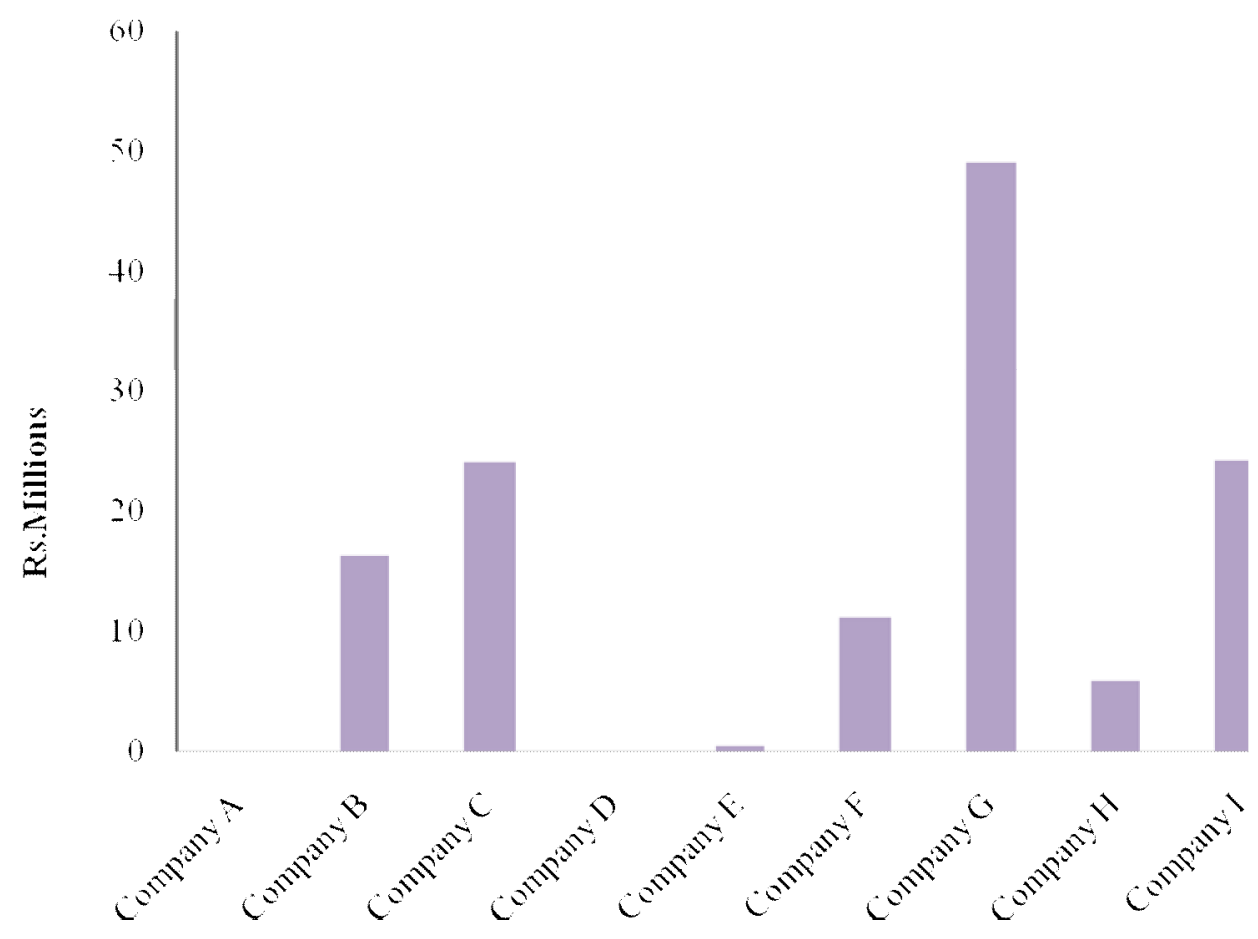

Source: Sri Lanka Customs (2010)

\section{Fig. 1. Values of exported green tea bags in 2009}

\section{Outreach to mixed market}

The business strategy of Company $\mathrm{F}$ includes taking their value added branded tea to the warehouses in the USA, and selling from there. This operation is generally practised by the importers in the respective countries and they distribute tea to the consumers. The CEO has taken a strategic decision to cut down one link in the market chain and do away with the importers thereby gain the advantage of the foregone margin. Although this is seen as hard to practice, he proudly mentioned that it is successful. They have a coordinating office in the United States but the activities are operated from the head office in Sri Lanka. The usual practice is that the company gets the orders from the Department Stores, pack in Sri Lanka, send them to the warehouse and the order is collected from the warehouse in the USA. From the warehouse the product is sold out to various people.

This company has strategically outreached in business operations to the UK and several other European countries. The company is selling about 10 brands of their own and altogether about 60 brands including brands owned by other companies. Moreover, they operate in a mixed market i.e. they serve from very small customer to the large customer. 


\section{Quick delivery of innovative tea packs}

The main business strategy of Company $\mathrm{H}$ is promptness. The CEO believes that the orders should be provided within two to three days without dragging for weeks, which affect the quality of tea. Maintaining constant delivery times and continuity in operations are considered important strategies to be successful in the market. Giving an open picture to the clients about what can be done and what cannot be done is a strategy to build up confidence and to maintain a good rapport with them. The CEO believes that the first impression is the last impression and therefore choosing the correct business approach is strategically important in marketing.

Taking care of the customer is another important strategy adopted by the company. A personalized service was rendered and the clients are treated like family members. These relationships are important to generate more and more products in the segment. His vision is to develop new products through which he believes could create new clients. With this vision from the inception he produced value added tea and the latest addition is the gift sector. He visualized innovating basic tea into gift packaging as a way of generating more foreign exchange.

The summary of strategies adopted by nine value added tea exporting firms, which were identified through data gathered through interviews, are presented in Table 3.

\section{Table 3. Strategies adopted by value added tea exporting firms}

\begin{tabular}{ll}
\hline Company & \multicolumn{1}{c}{ Strategy } \\
\hline A & Product differentiation, cost leadership and niche market \\
B & Branding, niche market, market diversification and customer focus \\
C & Niche market, branding and R\&D innovation \\
D & Tea marketing, niche market, cost leadership, customer focus and \\
& R\&D \\
E & Customer focus and strategic partnerships \\
F & Market diversification and outreach \\
G & Environmental sustainability, fair trade and innovation \\
H & Quick delivery, customer care and innovation \\
I & Branding, internal and external customer focus, freshness and \\
& quality, vertical integration \\
\hline
\end{tabular}

Having discussed different strategies adopted by the value added tea exporting firms to win the competitive advantage, it is important to consider the total value of tea exported by these firms as a measure of their success. Total values of tea exports including bulk tea exports are presented in Fig. 2. According to Fig. 2 companies are performing well in tea exports emphasising the need for product and market innovation strategies. The differences in tea exports observed among the companies could be due to their operating markets, type of the products, and the strategies adopted. However, export performances of the companies cannot be compared due to their different scales of operations, period of establishment and other related internal and external factors. 


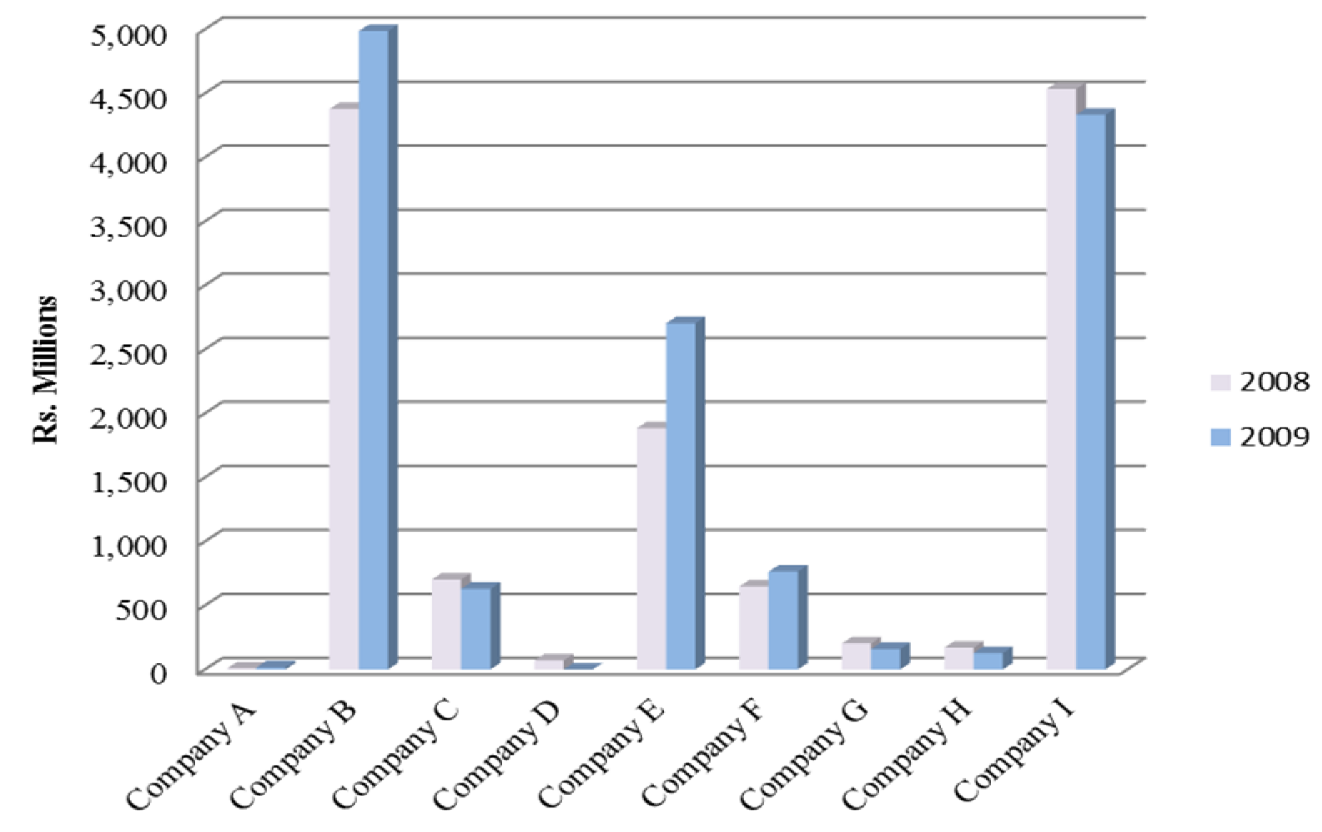

Source: Sri Lanka Customs (2010)

Fig. 2. Value of total tea exports in 2008 and 2009

\section{CONCLUSION}

The analysis helped to shed light on the various strategies adopted by the Sri Lankan value added tea export firms in gaining the competitive advantage over their competitors. The study revealed a variety of marketing and innovation strategies adopted by the firms. Product differentiation, cost leadership, niche marketing, branding and customer focus were found as the strategies adopted by most of the firms. In addition, each firm had its own set of strategies, which differentiate it from others and give competitive advantage over its competitors. Some of these specific strategies include fair trade, environment sustainability, strategic partnerships, outreach, market diversification and quick delivery. The firms have introduced new products to the market as well as extended the existing product range according to the growing market demand. Opening up new markets abroad has been an important strategy that placed the firms among the market leaders. When the tea sales values are considered, it is apparent that the firms that have outperformed their competitors in sales have adopted customer focus as a common strategy. The firm that pioneered in value added tea with the production of branded tea bags is the market leader in total exports

While innovation is fundamental in gaining competitive advantage, combining the innovative efforts with appropriate strategy is found as vital for winning the competitive markets. The unseen force that brings innovation and strategy together is the leadership of the pioneers of the organizations. It was revealed through the case study that the inspiring role of the leaders, their commitment, innovative thinking and above all their vision can be attributed to the success of the firms. While many CEOs were very enthusiastic and motivated about their 
value added market operations for expansion, a few were trying to maintain their market share through value addition.

The results suggest that adopting marketing and innovation strategies, depending on the firm's capabilities and competencies rather than just let it happen by default, is vital for the value added tea export firms to achieve business success as well as contribute substantially to the Sri Lankan economy.

\section{ACKNOWLEDGEMENTS}

Authors thank Professor Sudatta Ranasinghe, Open University of Sri Lanka for his valuable comments; The Open University Distance Education Modernization Project of the ADB for funding the research; and all the firms participated in the study.

\section{REFERENCES}

Choudhry, Y., Lister, D.W. and Ali, R. (1997). Sri Lanka's tea industry: succeeding in the global market. World Bank Discussion Paper No 360.

De Silva, S. and Takeda, J. (2005). Strategic orientation for product innovation in developing countries: The case of food processing firms in Sri Lanka, Proceedings of the $79^{\text {th }}$ Annual Symposium of Japan Society of Business Administration, September. Kyushu University, Fukuoka, Japan. pp. 283-286.

De Silva, S. (2006). Organizational culture and management strategies for product innovation: A case study of food processing firms in Sri Lanka. Ph.D. thesis, United Graduate School of Kagoshima University, Japan.

Fonseka, D.C. (2009). Visionary leadership and the case of Dilmah, Sri Lankan J. Mgt. 14 (2), 1- 16.

Modder,W.D. and Amarakoon, A.M.T. (2002). Tea and health, Tea Research Institute, Thalawakele, Sri Lanka.

Organization for Economic Co-operation and Development (1997). OSLO manual: Proposed guidelines for collecting and interpreting technological innovation data, $2^{\text {nd }}$ edition. OECD

Porter, M. (1985).Competitive advantage; creating and sustaining superior performance, The Free Press, USA.

Porter, M. (1980).Competitive strategy; The Free Press, USA.

Sambasivam, T. (1996). The future of teas: A Sri Lankan perspective. Tea and coffee trade journal, the international voice of the tea and coffee industries 168(09), 38 - 44.

Wanninyake, W.M.C.B. and Dissanayake, D.M.R. (2006). Future prospects of value added tea sector of Sri Lanka, comparative study, proceedings of the annual research symposium 2006, Faculty of Graduate Studies, University of Kelaniya, Sri Lanka. 